\title{
Can the municipalities prevent medication of lifestyle related diseases?
}

\author{
MICKAEL BECH ${ }^{1}$, MAJA HANSEN ${ }^{2}$, \\ JØRGEN LAURIDSEN ${ }^{1, *}$ AND CHRISTIAN KRONBORG ${ }^{1}$ \\ ${ }^{1}$ Centre of Health Economic Research (COHERE), University of Southern Denmark \\ ${ }^{2}$ National Institute of Public Health, University of Southern Denmark
}

\begin{abstract}
In extension of a large municipality reform in 2007, which reduced the number of Danish municipalities from 275 to 98 , it was the intention that the municipalities should assume responsibility for a part of the expenditure connected to secondary sector health care treatment. Furthermore, the municipalities were assigned the responsibility for - and equipped with a number of opportunities for exerting primary preventive initiatives. The purpose of the present study is to investigate, whether the municipalities by applying these opportunities have been able to prevent medication of selected lifestyle related diseases (type 2 diabetes, cardiovascular diseases, and asthma and chronically obstructive lung disease). Though our results initially seem to support this, a closer investigation indicates that the relationship between municipal preventive initiatives and medication is a structural, intra-municipal relationship rather than a cause-response effect.
\end{abstract}

Key words: Medical treatment; lifestyle; type 2 diabetes; cardiovascular diseases; asthma and chronically obstructive lung disease; type 2 diabetes; spatial structures; small area variation; panel data

\section{Introduction}

The growth of public health expenditure is a major topic of policy debates in most Western countries. Following the seminal paper of Newhouse (1992), the study of determinants of health care expenditure has been a matter of extensive debate for more than two decades. This development has been reinforced by the increasing availability of national level data on health care, which has cast a large number of studies considering the effects of underlying factors such as income, demography and time effects (Gerdham and Johnsson 2000) and technology progress (Newhouse 1977, 1992; Gerdham and Johnsson 2000). However, most studies are based on cross-country data and thus fail to account for unobservable institutional factors. Restricting the analysis to a single country may, to an extent, reduce part of this heterogeneity across countries (Di Matteo and Di Matteo 1998; Gianonni and Hittris 2002; Revelli 2001, 2002).

The present study focuses on the variation in medication of lifestyle related diseases across the Danish municipalities. Specifically, focus will be on medication against type 2 diabetes, cardiovascular conditions, and asthma and chronically obstructive lung disease (COL), as these are commonly accepted to be especially connected to unhealthy life style, which in turn potentially may be affected during municipal efforts and 
policies. One can think of a further number of factors determining medication such as socio-demographic variables, morbidity and mortality, availability of primary care services etc. These determinants may, however, not be randomly distributed across the geographical units but may have underlying spatial patterns. A non-random underlying spatial pattern may if ignored bias the significance of the determinants (Case m.fl. 1993, Revelli 2002) and invalidate conclusions. Proper analyses of the spatial dynamics in the variation and its' determinants may furthermore enclose important information for policy debates informing policy makers about a more complex pattern of variation partly determined by spatial geographic mechanisms. Spatial mechanisms may emerge from several sources. Competition and learning effects among spatially clustered municipalities may lead to spatial clustering of health care behaviour, i.e. endogenous spatial spillover may be in play. Furthermore, exogenous spatial spillover may exist. Specifically, observed or unobserved determinants may affect the health care behaviour, not only in the municipality where they are observed, but also in a surrounding cluster of municipalities. Examples of such endogenous spillover readily occur. Provision of services at the regional level which partly induce or prevent medication may exert influence beyond the regional borderline. Likewise, medication of lifestyle related diseases may be affected by economic, demographic, social, labour market and urbanisation structures of the neighbouring regions. Finally, the very existence of spatial clustering of medication practice together with spatial clustering of observed as well as unobserved determinants may lead to spurious regression, in the sense that estimated relationships present themselves as stronger than they really are. At the extreme, variables, which are unrelated apart from being independently spatially clustered, may in such cases seem to be significantly related. Indeed, not accounting for spatial dynamics has been shown to potentially lead to biased and inefficient estimates of the parameters of an equation of public expenditure determination (Revelli 2002, Case et al. 1993).

Only a few studies of small-area variation have considered the nature and implications of spatial variation in medical practice. Westert et al. (2004) found spatial disparities in hospital discharges. Joines et al. (2003) found that hospitalization rates for low back problems varied significantly across the counties of North Carolina. They also found that counties with similar rates clustered geographically and concluded that spatial effects are important and should be considered in SAV studies. Moscone and Knapp (2005) and Moscone et al. (2007) explored the spatial patterns of mental health expenditure and concluded that it was important to control for spatial spillover. The latter two studies found a significant spatial effect suggesting that adjacent local authorities mimic their neighbours and tend to have similar mental health expenditure. Costa-Font \& Pons-Novell (2007) showed in their analysis of the public health care expenditure in the Spanish regions that a significant spatial dependence is present. Finally, studies of the Spanish pharmaceutical market have shown considerable tendencies to spatial dependence (Bech et al., 2010; Lauridsen et al., 2007, 2008, 2010a, 2010b).

Yet another stream of studies applies panel data methods to account for potential unobservable differences in tastes and preferences in the health care expenditure function. Some evidence (Gianonni and Hittris 2002; Gerdham and Johnsson 2000; Di Matteo and Di Matteo 1998) uses various forms of times series cross section analysis, including random or fixed effects specifications. However, none of these consider spatial interactions. Furthermore, the standard panel data methods applied are quite simplistic and thus fall into one of two caveats by being either heavily over-parameterized (e.g. fixed effects panel data specifications) or very parsimoniously parameterized (e.g. random effects panel data specifications). In-between forms allowing for time decay in intraregional correlation (for example the seemingly unrelated regression approach) seldom 
find application. One aim of the present study is to integrate the seemingly unrelated regression approach with spatial spillover specifications in order to provide an investigation of the simultaneous importance of panel effects and spatial effects

To summarise, the threefold purpose of this study is 1) to explore the determinants of the variation in medication of lifestyle related diseases and to explore whether the municipalities can prevent such medication; 2) to control for selected characteristics of the health care system, and 3) to demonstrate the necessity of adjustment for heterogeneity and dependency across years as well as spatial spillover effects and to disclose the spatial dynamics in the determinants of medication.

The results of the study have important relevance for the health policy debate about the municipalities co-financing of health care services. Specifically, subsequent to a large reform, initiated at January $1^{\text {st }} 2007$, and which reduced the number of Danish municipalities from 275 to 98 , the municipalities were obligated to pay a fee per inhabitant to the secondary sector - i.e. the hospital sector governed by the five Danish regions together with a payment which varied according to their citizens' health care consumption. The purpose of this reform was that the municipalities should be given an incentive for reducing their citizens' utilisation of health care services. With respect to this intention, the results from the present study are not very optimistic, but they are in accordance with earlier studies (Bech and Lauridsen, 2008, 2009a, 2009b, 2009c), which were unable to show any relationship between municipal policy initiatives and utilisation of health care. However, while the previous studies were based on data from the old municipality structure, the present work applies data from after the reform; one might therefore expect another conclusion.

Furthermore, statistics on consumption of pharmaceuticals are used as indicators to describe public health problems in the municipalities in order for health care authorities, including the municipalities, to base decisions on this information (Lægemiddelstyrelsen, 2010). However, the results from this study questions whether public policy decision can be based on such statistics. First, as mentioned above, variation in the consumption of pharmaceuticals may reflect differences in health among different municipalities as well as variation in health care provision among providers. Second, it may reflect differences in health behaviour among citizens in various municipalities, e.g. in terms of seeking help in case of symptoms. Third, use of prescription drugs also requires that patients' collect their prescription at community pharmacies. 


\section{Data}

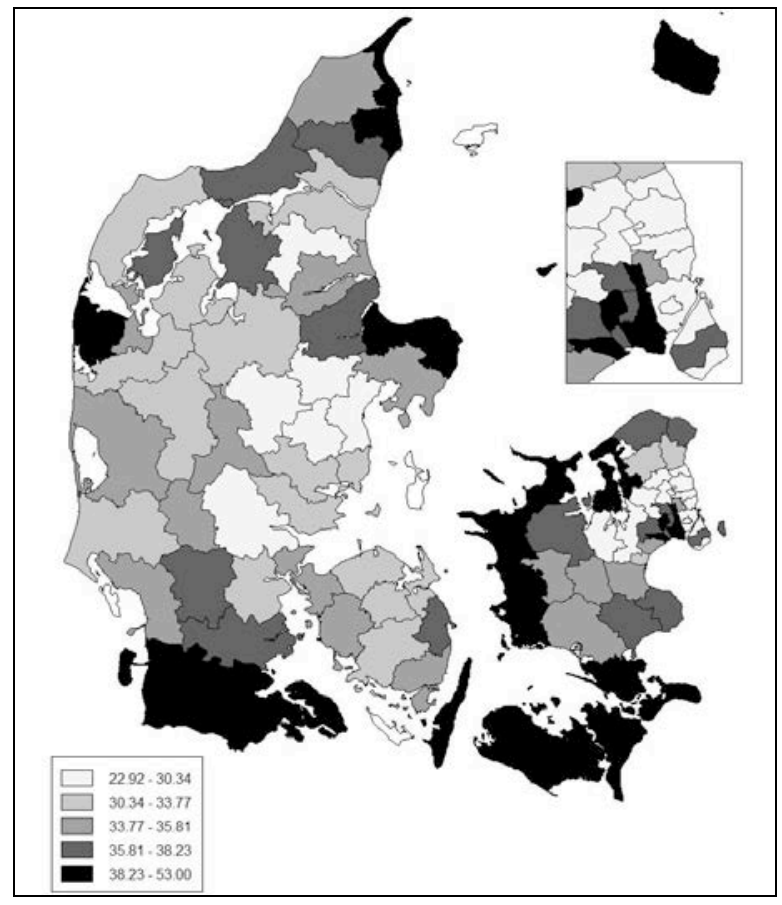

Figure 1. Number of medicated for type 2 diabetes per 1000 inhabitants

Data were collected from The Key Figure Database at the Ministry of the Interior Health and from The Statistical Bank at Statistics Denmark for the period 2007-2009 forming a balanced panel data set with data from 94 municipalities. Of the 98 newly formed municipalities, four were small island municipalities having special agreements with the government so that they differed with respect to data and other conditions. The three dependent focus variables are the number of persons assuming medical treatment for type 2 diabetes, for cardiovascular diseases, and for asthma / COL, all per 1,000 inhabitants. Figure 1 shows the geographical variation in medication for type 2 diabetes for 2009; it is seen that between two and five percent of the population receives such a medication. Furthermore, it is seen that the number of medicated is high in certain peripheral areas, while it is especially low in the capitol area and in the central part of the Jutland peninsula. Finally, there are certain tendencies to spatial clustering of data. 


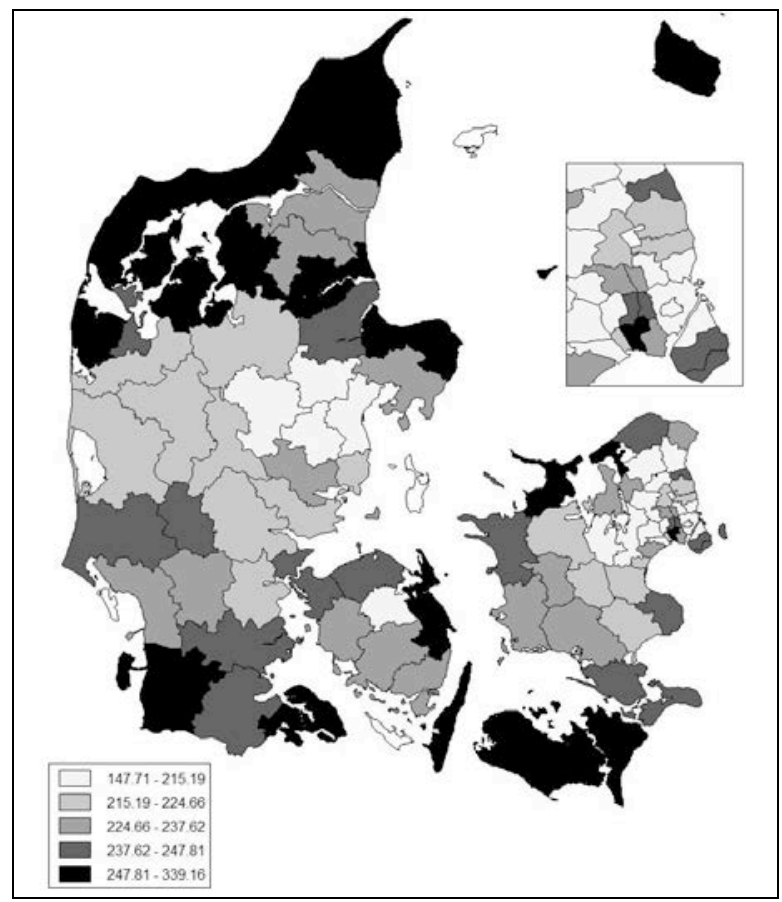

Figure 2. Number of medicated for cardiovascular diseases per 1000 inhabitants

Figure 2 shows the geographical distribution of medication for cardiovascular diseases. The picture is somewhat similar to what was seen for diabetes medication; high numbers of medicated are especially found in peripheral areas while these figures are small for the capitol area and the central part of the Jutland peninsula, and tendencies to spatial clustering are present. It is seen that between 15 and 34 percent of the population receives medication for cardiovascular diseases.

Figure 3 shows the geographical variation in medication for asthma / COL. It is seen that between zero and 10 percent of the population is medically treated for such diseases. Opposed to what was found for diabetes and for cardiovascular diseases, the geographical distribution is less intuitive, as high numbers of medicated seem to be found in peripheral as well as central areas. However, relatively strong tendencies to spatial clustering seem to be present. 


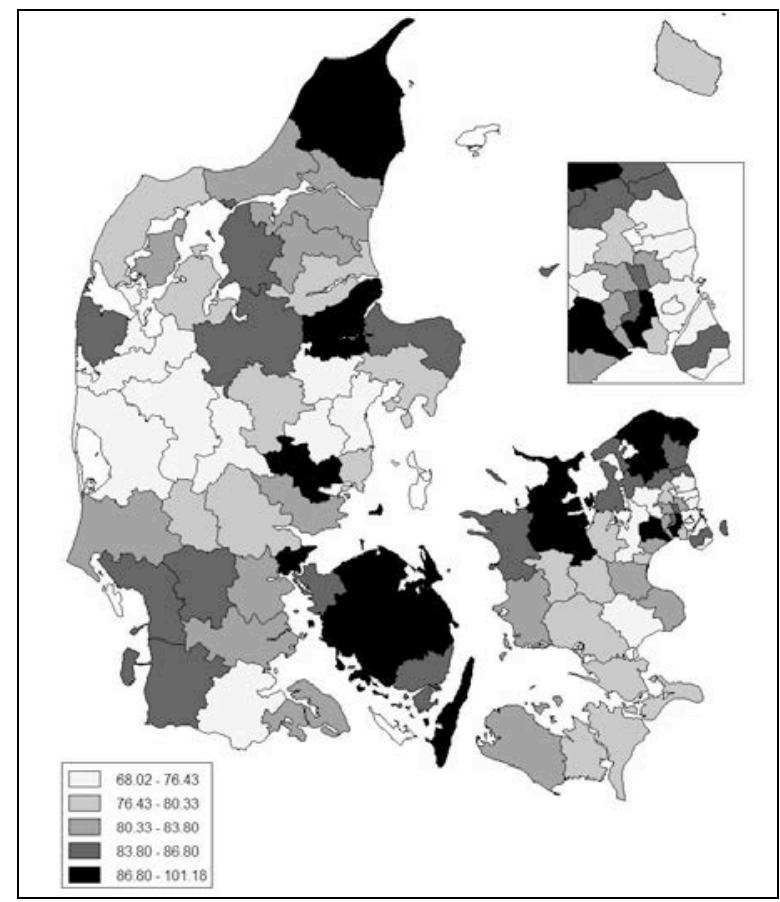

Figure 3. Number of medicated for asthma / COL per 1000 inhabitants

The explanatory factors fall in three main groups. The first group, which calls for primary attention, is variables, which the municipalities to some extent can control, and through which the number of persons medicated can - directly or indirectly by intervention in their lifestyle - be affected. This group includes an indicator for whether the municipality has a formal health policy statement or not, and the municipal expenditure to health care, divided into expenditure for activity based co-financing; expenditure for health promotion and disease prevention; expenditure for municipal health care service; and other health expenditure. If these factors have significant effects, then evidence is provided that the municipalities during their policy practice may affect the number of persons medicated. Apart from these variables, other measures of policy have been considered, including elder care, expenditure for sport and leisure etc. However, data were not at the moment of the study available from all municipalities on these measures, so that they had to be discarded.

The second group consists of variables describing the supply of health care deliveries like general practice and specialist practice. Such variables are out of municipal control and include different measures for density of providers (general practitioners and specialist practitioners) as well as consumption of treatment as measured by the number of GP visits.

The third category of variables is a variety of traditional control variables like urbanisation, unemployment, social and demographic variables etc. Such factors are included as they may have direct effects on medication as well as mediating the effects of the factors outlined under the first and second group. 
Table 1. Description of data

\begin{tabular}{|c|c|c|c|c|}
\hline Variable & Definition & Average & $\begin{array}{l}\text { Std. } \\
\text { dev. }\end{array}$ & $\begin{array}{l}\text { Expected } \\
\text { sign }\end{array}$ \\
\hline Diabetes & $\begin{array}{l}\text { Number of persons in medical treatment } \\
\text { for type } 2 \text { diabetes per } 1000 \text { inhabitants }\end{array}$ & 33.19 & 5.43 & $\begin{array}{l}\text { (Dep. } \\
\text { variable) }\end{array}$ \\
\hline Cardiovascular & $\begin{array}{l}\text { Number of persons in medical treatment } \\
\text { for cardiovascular diseases } \\
\text { per } 1000 \text { inhabitants }\end{array}$ & 227.0 & 25.83 & $\begin{array}{l}\text { (Dep. } \\
\text { variable) }\end{array}$ \\
\hline Asthma / COL & $\begin{array}{l}\text { Number of persons in medical treatment } \\
\text { for asthma or COL per } 1000 \text { inhabitants }\end{array}$ & 82.83 & 7.16 & $\begin{array}{l}\text { (Dep. } \\
\text { variable) }\end{array}$ \\
\hline \multicolumn{5}{|c|}{ Under municipal control: } \\
\hline Health policy & Health policy implemented $(1=$ yes, $0=$ no $)$ & 0.81 & 0.38 & - \\
\hline Co-financing & $\begin{array}{l}\text { Expenditure for activity based co- } \\
\text { financing of health care services } \\
\text { (1000 DKK per inhabitant) }\end{array}$ & 1.74 & 0.18 & - \\
\hline Prevention & $\begin{array}{l}\text { Expenditure for health promotion and } \\
\text { disease prevention } \\
\text { (1000 DKK per inhabitant) }\end{array}$ & 0.05 & 0.05 & - \\
\hline Health services & $\begin{array}{l}\text { Expenditure for municipal health care } \\
\text { service ( } 1000 \text { DKK per inhabitant) }\end{array}$ & 0.15 & 0.03 & - \\
\hline Health care & $\begin{array}{l}\text { Expenditure for other kinds of health } \\
\text { care (1000 DKK per inhabitant) }\end{array}$ & 0.09 & 0.04 & - \\
\hline \multicolumn{5}{|l|}{ Supply factors: } \\
\hline GP density & Number of GPs per 1000 inhabitants & 0.65 & 0.07 & $-/+$ \\
\hline $\begin{array}{l}\text { GP practice } \\
\text { density }\end{array}$ & $\begin{array}{l}\text { Number of GP practices } \\
\text { per } 1000 \text { inhabitants }\end{array}$ & 0.38 & 0.10 & $-/+$ \\
\hline GP visits & $\begin{array}{l}\text { Number of GP visits } \\
\text { per } 1000 \text { inhabitants }\end{array}$ & 7.30 & 0.47 & $-/+$ \\
\hline $\begin{array}{l}\text { GP } \\
\text { expenditure }\end{array}$ & $\begin{array}{l}\text { Expenditure for GP visits } \\
\text { (1000 DKK per inhabitant) }\end{array}$ & 1.23 & 0.12 & $-/+$ \\
\hline $\begin{array}{l}\text { Specialist } \\
\text { visits }\end{array}$ & $\begin{array}{l}\text { Number of specialist visits } \\
\text { per } 1000 \text { inhabitants }\end{array}$ & 0.89 & 0.27 & $-/+$ \\
\hline \multicolumn{5}{|l|}{ Other factors: } \\
\hline Zealand & $\begin{array}{l}\text { Municpality in the Zealand region } \\
(1=\text { yes, } 0=\text { no })\end{array}$ & 0.18 & 0.38 & $?$ \\
\hline $\begin{array}{l}\text { Northern } \\
\text { Jutland }\end{array}$ & $\begin{array}{l}\text { Do., in the Northern Jutland region } \\
(1=\text { yes, } 0=\text { no })\end{array}$ & 0.21 & 0.40 & $?$ \\
\hline Central Jutland & $\begin{array}{l}\text { Do., in the Southern Jutland region } \\
(1=\text { yes, } 0=\text { no })\end{array}$ & 0.19 & 0.39 & $?$ \\
\hline $\begin{array}{l}\text { Southern } \\
\text { Denmark }\end{array}$ & $\begin{array}{l}\text { Do., in the Southern Denmark region } \\
(1=\text { yes, } 0=\text { no })\end{array}$ & 0.11 & 0.30 & $?$ \\
\hline $\begin{array}{l}\text { Right wing } \\
\text { mayor }\end{array}$ & $\begin{array}{l}\text { Mayor from right-wing party } \\
(1=\text { yes, } 0=\text { no })\end{array}$ & 0.43 & 0.49 & $?$ \\
\hline $\begin{array}{l}\text { Local / Centre } \\
\text { mayor }\end{array}$ & $\begin{array}{l}\text { Mayor from local list or centre party } \\
(1=\text { yes, } 0=\text { no })\end{array}$ & 0.05 & 0.22 & $?$ \\
\hline $\begin{array}{l}\text { Intermediate } \\
\text { area }^{1}\end{array}$ & $\begin{array}{l}\text { Municipality in intermediate area } \\
(1=\text { yes, } 0=\text { no })\end{array}$ & 0.18 & 0.38 & $?$ \\
\hline Rural area $^{1}$ & Do., rural area $(1=$ yes, $0=$ no $)$ & 0.30 & 0.46 & ? \\
\hline
\end{tabular}




\begin{tabular}{|c|c|c|c|c|}
\hline $\begin{array}{l}\text { Peripheral } \\
\text { area }^{1}\end{array}$ & Do., peripheral area $(1=$ yes, $0=$ no $)$ & 0.13 & 0.34 & $?$ \\
\hline Urbanisation & $\begin{array}{l}\text { Percentage of inhabitants living in urban } \\
\text { areas }\end{array}$ & 83.3 & 11.97 & $?$ \\
\hline $\begin{array}{l}\text { Socio- } \\
\text { economic }\end{array}$ & $\begin{array}{l}\text { Expenditure need of the municipality } \\
\text { relative to other municipalities (index) }\end{array}$ & 0.93 & 0.24 & $?$ \\
\hline Welfare & $\begin{array}{l}\text { Municipal welfare level relative to other } \\
\text { municipalities (index) }\end{array}$ & 149.6 & 28.07 & $?$ \\
\hline Unemployment & $\begin{array}{l}\text { Percentage of unemployed } \\
\text { (18-64 year-old) }\end{array}$ & 2.53 & 1.02 & $+(?)$ \\
\hline Social benefit & $\begin{array}{l}\text { Percentage 18-64 year-old on social } \\
\text { benefit }\end{array}$ & 4.08 & 1.45 & + \\
\hline $\begin{array}{l}\text { Sickness } \\
\text { benefit }\end{array}$ & $\begin{array}{l}\text { Expenditure for sickness benefit } \\
\text { (1000 DKK per 17-64 year-old) }\end{array}$ & 3.46 & 0.62 & + \\
\hline $\begin{array}{l}\text { Sickness } \\
\text { retirement }\end{array}$ & $\begin{array}{l}\text { Percentage of 18-64 year-old on sickness } \\
\text { retirement }\end{array}$ & 5.12 & 1.56 & + \\
\hline $\begin{array}{l}\text { Children out } \\
\text { of home }\end{array}$ & $\begin{array}{l}\text { Expenditure for placing children out of } \\
\text { home ( } 1000 \text { DKK per } 0-17 \text { year old) }\end{array}$ & 12.56 & 3.83 & $?$ \\
\hline $\begin{array}{l}\text { Further } \\
\text { education }\end{array}$ & $\begin{array}{l}\text { Percentage } 25-64 \text { year-old with further } \\
\text { education }\end{array}$ & 21.84 & 7.92 & - \\
\hline No prof. educ. & $\begin{array}{l}\text { Percentage } 25-64 \text { year-old without } \\
\text { professional educ. }\end{array}$ & 24.48 & 5.44 & + \\
\hline In-commuting & $\begin{array}{l}\text { Number of in-commuters per } 100 \\
\text { fulltime employed }\end{array}$ & 39.09 & 20.48 & $?$ \\
\hline $\begin{array}{l}\text { Out- } \\
\text { commuting }\end{array}$ & $\begin{array}{l}\text { Number of out-commuters per } 100 \\
\text { fulltime employed }\end{array}$ & 45.91 & 28.94 & $?$ \\
\hline Female & Percentage of female inhabitants & 50.36 & 0.81 & $?$ \\
\hline $7-16$ year-old & Percentage of 7-16 year-old inhabitants & 13.35 & 1.29 & $?$ \\
\hline 17-25 year-old & Percentage of $17-25$ year-old inhabitants & 8.98 & 1.74 & $?$ \\
\hline 26-35 year-old & Percentage of 26-35 year-old inhabitants & 11.12 & 2.34 & $?$ \\
\hline 36-66 year-old & Percentage of 36-66 year-old inhabitants & 43.99 & 2.33 & $?$ \\
\hline $67+$ year-old & Percentage of $67+$ year-old inhabitants & 14.16 & 2.18 & $?$ \\
\hline Widowed & Percentage of widowed inhabitants & 6.05 & 0.99 & $?$ \\
\hline Divorced & Percentage of divorced inhabitants & 7.61 & 1.26 & $+(?)$ \\
\hline Unmarried & Percentage of unmarried inhabitants & 43.84 & 3.40 & $?$ \\
\hline
\end{tabular}

Note. ": Municipalities distributed according to a classification system based on 14 criteria described by "The National Strategy for the Danish Rural Area Programme 2007-2013”. Reference group is urban areas

Table 1 provides a full overview over the study variables, including which of the three groups they belong to, their exact definition, average and standard deviation, and the expected sign of their effect (positive and/or negative) on the number of medicated persons. 


\section{Quantitative method}

The point of departure is a linear regression model which relates the number of medicated persons per 1000 inhabitants per year linearly to the determinants. Assuming initially a cross-section of $N=98$ municipalities observed for a year $t$, this linear specification reads as

$$
y_{t}=X_{t} \beta+v_{t}, \quad v_{t} \sim N\left(0, \sigma^{2} I\right)
$$

where $X_{t}$ is an $N \times K$ dimensional matrix of explanatory variables, $y_{t}$ an $N$ dimensional vector of number of medicatited, $\beta$ a $K$ dimensional coefficient vector, and $v_{\mathrm{t}}$ is a $N$ dimensional vector error term. Applying pooled data for $T=3$ years leads to $T=3$ equations, one for each year. The residuals of the $\mathrm{T}$ equations are generally inter-correlated, and the variances for the cross-sections vary over years. Between any two years the residual covariance reads as

$$
E\left(v_{t} v_{s}^{\prime}\right)=\sigma_{t s}^{2} I, \quad t, s=1, . ., T
$$

The model defined by combining (1)-(2) may be estimated efficiently by using Seemingly Unrelated Regression (SUR) (Zellner 1962). This technique resembles the well known Random Effect (RE) - and Fixed Effects (FE) specifications, as they adjust for intra-class correlation, i.e. the phenomenon that any individual municipality may stabilise its behaviour over time. The SUR specification, however, is more flexible than the RE, as it specifies one correlation parameter per pair of years, and statistically more efficient than FE, which estimates a distinctive parameter for each municipality.

To initially make the concept of spatial spillover operational in a one-year model a common approach is to specify an $\mathrm{N} \times \mathrm{N}$ matrix $\mathrm{W}$ so that wij equals 1 if municipalities $\mathrm{i}$ and $j$ are neighbours $(i \neq j)$ and 0 otherwise, and divide each element in $W$ with the number of non-zero elements in the row it belongs to. Then the product $W y_{t}$ defines a variable, which for each municipality holds the average of number of medicated in the neighbouring municipalities. The endogenous spatial spillover is captured by a spatially autoregressive (SAR) specification on the form (Anselin 1988)

$$
y_{t}=\lambda\left(W y_{t}\right)+X_{t} \beta+v_{t},
$$

where $\lambda$ is a parameter specifying the degree of spillover, formally restricted to the interval between $(-1)$ and $(+1)$, but for most practical purposes restricted to be nonnegative. An alternative approach commonly applied is to jointly account for (observed as well as unobserved) endogenous and exogenous spatial spillover by applying the spatially autocorrelated (SAC) specification (Anselin 1988)

$$
y_{t}=X_{t} \beta+\varepsilon_{t}, \varepsilon_{t}=\lambda W \varepsilon_{t}+v_{t} .
$$

By combining (1) and (2) with either (3) or (4), specifications are obtained which simultaneously control for panel structures and spatial spillover effects.

To provide devices for comparison of alternative models some quantities are applied. One is a pseudo-R-square $\left(R^{2}\right)$, calculated as the square of the correlation between $y$ and its predicted values. This measure is readily calculated for the SUR and 
the SAC-SUR models, but is not defined for the SAR-SUR specification. A second device applied is the familiar Akaike Information Criterion (AIC). Finally, nested models are tested against each other using Likelihood Ratio (LR) test, calculated as twice the difference between the values of the log likelihoods of the two models.

\section{Results and discussion}

Table 2 presents results for type 2 diabetes from the SAC-SUR specification which simultaneously controls for endogenous and exogenous spatial spillover, and the SARSUR specification which controls for endogenous spatial effects only. Both specifications control for panel structures. For matter of comparison, results are reported from the SUR specification, which accounts for panel structures but not for spatial spill over, and from the simple OLS specification which accounts for neither of these.

Table 2. Estimated specifications for type 2 diabetes

\begin{tabular}{|c|c|c|c|c|}
\hline & OLS & SUR & SAC-SUR & SAR-SUR \\
\hline Constant term & $124.9(52.1)^{* *}$ & $11.45(52.11)$ & $13.05(51.7)$ & $7.68(51.0)$ \\
\hline Health policy & $-0.71(0.34)^{* *}$ & $-0.17(0.22)$ & $-0.14(0.21)$ & $-0.15(0.21)$ \\
\hline Co-financing & $4.84(1.12)^{* * *}$ & $2.70(0.88)^{* * *}$ & $2.81(0.90)^{* * *}$ & $2.49(0.87)^{* * *}$ \\
\hline Prevention & $2.98(3.38)$ & $-1.87(2.58)$ & $-2.74(2.57)$ & $-2.43(2.58)$ \\
\hline Health services & $13.66(5.53)^{* *}$ & $9.46(5.67)^{*}$ & $7.52(5.51)$ & $7.92(5.59)$ \\
\hline Health care & $4.66(3.35)$ & $0.88(2.60)$ & $0.87(2.61)$ & $0.93(2.58)$ \\
\hline GP density & $-3.87(1.97)^{* *}$ & $-1.07(2.21)$ & $-1.33(2.15)$ & $-0.94(2.19)$ \\
\hline GP practice density & $0.42(1.72)$ & $-2.56(2.10)$ & $-2.21(2.03)$ & $-2.08(2.04)$ \\
\hline GP visits & $0.81(0.44)^{*}$ & $1.12(0.53)^{* *}$ & $0.97(0.52)^{*}$ & $1.28(0.53)^{* *}$ \\
\hline GP expenditure & $8.55(2.50)^{* * *}$ & $7.25(2.58)^{* * *}$ & $8.43(2.61)^{* * *}$ & $6.36(2.54)^{* *}$ \\
\hline Specialist visits & $-4.34(1.58)^{* * *}$ & $-1.96(1.78)$ & $-1.37(1.78)$ & $-1.73(1.75)$ \\
\hline Zealand & $-1.87(0.57)^{* * *}$ & $-2.27(0.77)^{* * *}$ & $-2.18(0.81)^{* * *}$ & $-2.42(0.75)^{* * *}$ \\
\hline Northern Jutland & $-5.24(0.77)^{* * *}$ & $-6.18(0.98)^{* * *}$ & $-5.78(1.04)^{* * *}$ & $-5.66(0.95)^{* * *}$ \\
\hline Central Jutland & $-5.01(0.78)^{* * *}$ & $-5.73(1.02)^{* * *}$ & $-5.26(1.08)^{* * *}$ & $-4.83(1.00)^{* * *}$ \\
\hline Southern Denmark & $-6.31(0.96)^{* * *}$ & $-6.34(1.18)^{* * *}$ & $-6.17(1.26)^{* * *}$ & $-5.66(1.16)^{* * *}$ \\
\hline Right wing mayor & $0.19(0.31)$ & $0.45(0.43)$ & $0.40(0.42)$ & $0.48(0.42)$ \\
\hline Local / Center mayor & $-0.17(0.65)$ & $0.62(0.90)$ & $-0.64(0.86)$ & $-0.42(0.87)$ \\
\hline 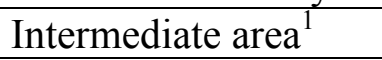 & $0.22(0.52)$ & $0.67(0.73)$ & $0.48(0.69)$ & $0.56(0.71)$ \\
\hline Rural area $^{1}$ & $0.63(0.68)$ & $0.78(0.93)$ & $0.50(0.92)$ & $0.47(0.91)$ \\
\hline 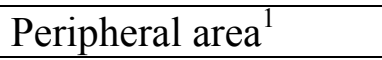 & $-0.44(1.05)$ & $-0.63(1.36)$ & $-0.80(1.34)$ & $-0.72(1.33)$ \\
\hline Urbanisation & $-0.04(0.03)$ & $-0.06(0.04)$ & $-0.07(0.04)^{*}$ & $-0.06(0.04)^{*}$ \\
\hline Socio-economic & $16.09(1.97)^{* * *}$ & $13.80(2.29)^{* * *}$ & $13.60(2.25)^{* * *}$ & $13.29(2.25)^{* * *}$ \\
\hline Welfare & $0.01(0.01)$ & $0.01(0.01)$ & $0.01(0.01)$ & $0.01(0.01)$ \\
\hline Unemployment & $0.11(0.17)$ & $-0.07(0.12)$ & $-0.04(0.13)$ & $-0.03(0.12)$ \\
\hline Social benefit & $-0.53(0.24)^{* *}$ & $0.03(0.22)$ & $0.01(0.21)$ & $-0.09(0.21)$ \\
\hline Sickness benefit & $0.35(0.40)$ & $0.15(0.33)$ & $0.14(0.33)$ & $0.13(0.32)$ \\
\hline Sickness retirement & $-0.13(0.20)$ & $-0.48(0.23)^{* *}$ & $-0.47(0.24)^{* *}$ & $-0.48(0.23)^{* *}$ \\
\hline Children out of home & $0.11(0.05)^{* *}$ & $0.14(0.06)^{* *}$ & $0.13(0.05)^{* *}$ & $0.09(0.06)^{*}$ \\
\hline Further education & $-0.45(0.07)^{* * *}$ & $-0.52(0.08)^{* * *}$ & $-0.47(0.08)^{* * *}$ & $-0.40(0.09)^{* * *}$ \\
\hline No prof. educ. & $-0.60(0.14)^{* * *}$ & $-0.42(0.17)^{* *}$ & $-0.35(0.17)^{* *}$ & $-0.26(0.17)$ \\
\hline In-commuting & $-0.01(0.02)$ & $0.03(0.02)$ & $0.03(0.02)^{*}$ & $0.03(0.02)$ \\
\hline Out-commuting & $-0.001(0.006)$ & $\begin{array}{l}-0.008 \\
(0.003)^{* * *}\end{array}$ & $\begin{array}{l}-0.007 \\
(0.003)^{* *}\end{array}$ & $\begin{array}{l}-0.008 \\
(0.003)^{* * *}\end{array}$ \\
\hline
\end{tabular}




\begin{tabular}{|l|l|l|l|l|}
\hline Females & $-1.05(0.42)^{* *}$ & $-0.52(0.51)$ & $-0.58(0.48)$ & $-0.41(0.50)$ \\
\hline 7-16 year-old & $-0.38(0.83)$ & $-0.42(0.71)$ & $-0.32(0.70)$ & $-0.31(0.69)$ \\
\hline $17-25$ year-old & $0.13(0.52)$ & $0.30(0.48)$ & $0.35(0.47)$ & $0.20(0.47)$ \\
\hline 26-35 year-old & $-0.49(0.70)$ & $-0.40(0.61)$ & $-0.24(0.60)$ & $-0.31(0.60)$ \\
\hline 36-66 year-old & $-0.41(0.51)$ & $0.61(0.48)$ & $0.62(0.47)$ & $0.46(0.46)$ \\
\hline $67+$ year-old & $-0.06(0.53)$ & $1.38(0.56)^{* *}$ & $1.33(0.54)^{* *}$ & $1.13(0.55)^{* *}$ \\
\hline Widowed & $0.69(0.68)$ & $-0.97(0.74)$ & $-0.80(0.74)$ & $-0.72(0.73)$ \\
\hline Divorced & $-0.09(0.42)$ & $-0.93(0.48)^{*}$ & $-0.89(0.47)^{*}$ & $-0.71(0.47)$ \\
\hline Unmarried & $-0.47(0.22)^{* *}$ & $0.41(0.26)$ & $0.28(0.26)$ & $0.25(0.25)$ \\
\hline Spatial spillover & & & $0.23(0.75)$ & $0.18(0.04)^{* * *}$ \\
\hline$R^{2}$ & 0.90 & 0.88 & 0.88 & \\
\hline LogL & -290.1 & -222.8 & -220.3 & -218.2 \\
\hline AIC & 666.2 & 541.7 & 536.5 & 532.3 \\
\hline LR test vs. OLS & & $134.5 * * *$ & $139.6^{* * *}$ & $143.8^{* * *}$ \\
\hline LR test vs. SUR & & & $5.0^{* *}$ & $9.2^{* * *}$ \\
\hline
\end{tabular}

Note. Numbers in parentheses are standard errors; significance indicated by *** $(1 \%), * *(5 \%), *(10 \%)$

Generally, the results from the SAC-SUR, SAR-SUR and SUR specifications appear much similar. This indicates that the spatial spillover effects, though statistically significant, are unrelated to the explanatory variables and their effects on medication behaviour. Comparing the three adjusted specifications to the unadjusted OLS specification, on the other hand, shows important differences. Thus, the R2 for the models seem to indicate that the OLS specification slightly overestimates the explanatory power of the variables; for the OLS an explanatory power of 90 percent is obtained, while it is two percent lower in the SUR - and the SAC-SUR specifications. Likewise, remarkable differences are found in magnitudes and significance levels of coefficients. Thus, the OLS model seems to indicate that implementation of a health policy may reduce medication, while the adjusted models reject such a relation. A potential explanation may be that the OLS specification mixes cause-response relations with structural, intra-municipal relationships. Thus, the relationship must rather be ascribed to structural, non-causal relationships, i.e., municipalities with a strong preference for health care promotion may have a preference for a low medication level, without these phenomena necessarily being causally related to each other. Furthermore, some differences are observed with respect to effects of supply side characteristics. While all specifications indicate positive relationships between GP expenditure and medication, the OLS model stands out by indicating substitution effects between GP density and specialist visits and medication for diabetes, which is rejected by the adjusted specifications. Generally, the specifications seem to agree on that GP practice density and GP visits are less related to medication. Next, some regional variation seems to be in play, as all four provincial regions seem to have lower levels of medication for diabetes than the capitol region. Regarding sociodemographic conditions, some effects on medication seem to be present. In particular, high education seems to reduce medication for diabetes, while medication tends to be higher in municipalities with many professionally educated. Likewise, there seem to be a relationship to number of children out of home, as municipalities with high percentages of such children seem to have higher levels of medication. Otherwise, social factors seem less connected to medication level, when adjusting for intra-municipal correlations; the simple OLS specification appears overly optimistic with respect to such effects. This is the case for percentage receivers of social benefit. On the other hand, there seems to be an effect of age, as municipalities with many elder have higher levels of 
medication for diabetes. Finally, there seem to remain some spatial variation in medication level, which is not fully captured by the explanatory factors.

Table 3. Estimated specifications for cardiovascular diseases

\begin{tabular}{|c|c|c|c|c|}
\hline & OLS & SUR & SAC-SUR & SAR-SUR \\
\hline Constant term & $-27.43(175.3)$ & $85.59(138.6)$ & $77.69(138.7)$ & $20.01(138.0)$ \\
\hline Health policy & $0.50(1.15)$ & $0.28(0.46)$ & $0.29(0.46)$ & $0.25(0.45)$ \\
\hline Co-financing & $17.40(3.77)^{* * *}$ & $0.46(1.85)$ & $0.50(1.86)$ & $0.48(1.82)$ \\
\hline Prevention & $9.61(11.37)$ & $-0.96(5.34)$ & $-1.17(5.36)$ & $-1.67(5.26)$ \\
\hline Health services & $23.90(18.59)$ & $-32.19(12.74) * *$ & $-31.74(12.75) * *$ & $-32.03(12.58)^{* *}$ \\
\hline Health care & $19.60(11.27)^{*}$ & $8.14(5.28)$ & $8.02(5.29)$ & $6.84(5.20)$ \\
\hline GP density & $-13.95(6.61)^{* *}$ & $-19.93(5.93) * * *$ & $-19.68(5.92)^{* * *}$ & $-19.03(5.87)^{* * *}$ \\
\hline GP practice density & $8.92(5.80)$ & $-3.49(5.48)$ & $-3.55(5.47)$ & $-3.72(5.45)$ \\
\hline GP visits & $1.43(1.48)$ & $-0.22(1.56)$ & $-0.17(1.56)$ & $0.21(1.55)$ \\
\hline GP expenditure & $27.26(8.41)^{* * *}$ & $43.18(6.76) * * *$ & $43.02(6.78) * * *$ & $39.54(6.73)^{* * *}$ \\
\hline Specialist visits & $-10.23(5.34)^{*}$ & $-0.59(4.79)$ & $-0.56(4.81)$ & $-0.56(4.75)$ \\
\hline Zealand & $5.26(1.92)^{* * *}$ & $5.06(2.81)^{*}$ & $4.99(2.83)^{*}$ & $3.68(2.86)$ \\
\hline Northern Jutland & $9.90(2.59)^{* * *}$ & $11.18(3.53)^{* * *}$ & $11.13(3.56)^{* * *}$ & $9.82(3.58) * * *$ \\
\hline Central Jutland & $8.19(2.65)^{* * *}$ & $8.35(3.69)^{* *}$ & $8.29(3.72)^{* *}$ & $7.83(3.74)^{* *}$ \\
\hline Southern Denmark & $18.19(3.24)^{* * *}$ & $23.52(4.31)^{* * *}$ & $23.38(4.35)^{* * *}$ & $21.64(4.38)^{* * *}$ \\
\hline Right wing mayor & $1.16(1.07)$ & $1.55(1.65)$ & $1.55(1.64)$ & $1.84(1.67)$ \\
\hline Local / Center mayor & $1.54(2.19)$ & $0.55(3.35)$ & $0.61(3.33)$ & $1.81(3.41)$ \\
\hline 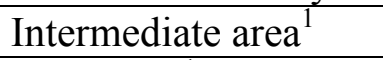 & $-0.72(1.77)$ & $3.77(2.71)$ & $3.68(2.70)$ & $3.77(2.76)$ \\
\hline Rural area $^{1}$ & $-2.07(2.32)$ & $5.90(3.39)^{*}$ & $5.81(3.40)^{*}$ & $5.57(3.44)$ \\
\hline Peripheral area $^{1}$ & $-4.49(3.55)$ & $8.22(4.84)^{*}$ & $8.05(4.85)^{*}$ & $8.05(4.90)^{*}$ \\
\hline Urbanisation & $0.55(0.10)^{* * *}$ & $0.40(0.14)^{* * *}$ & $0.40(0.14)^{* * *}$ & $0.38(0.14)^{* * *}$ \\
\hline Socio-economic & $16.05(6.65)^{* *}$ & $15.98(6.52)^{* *}$ & $15.80(6.52)^{* *}$ & $13.50(6.51)^{* *}$ \\
\hline Welfare & $0.02(0.02)$ & $0.01(0.01)$ & $0.01(0.01)$ & $0.01(0.01)$ \\
\hline Unemployment & $-0.40(0.58)$ & $-1.30(0.24)^{* * *}$ & $-1.29(0.24)^{* * *}$ & $-1.16(0.23)^{* * *}$ \\
\hline Social benefit & $-1.87(0.81)^{* *}$ & $-0.10(0.50)$ & $-0.12(0.50)$ & $-0.15(0.49)$ \\
\hline Sickness benefit & $0.71(1.35)$ & $1.01(0.68)$ & $0.99(0.68)$ & $1.01(0.67)$ \\
\hline Sickness retirement & $0.34(0.69)$ & $-1.21(0.77)$ & $-1.24(0.77)$ & $-1.29(0.77)^{*}$ \\
\hline Children out of home & $0.22(0.17)$ & $0.43(0.15)^{* * *}$ & $0.43(0.15)^{* * *}$ & $0.37(0.14)^{* *}$ \\
\hline Further education & $-0.53(0.23)^{* *}$ & $-0.81(0.27)^{* * *}$ & $-0.82(0.27)^{* * *}$ & $-0.76(0.27)^{* * *}$ \\
\hline No prof. educ. & $0.20(0.47)$ & $-0.32(0.54)$ & $-0.30(0.54)$ & $-0.13(0.54)$ \\
\hline In-commuting & $0.01(0.05)$ & $0.11(0.07)$ & $0.10(0.07)$ & $0.11(0.07)^{*}$ \\
\hline Out-commuting & $0.05(0.02)^{* * *}$ & $0.01(0.01)$ & $0.01(0.01)$ & $0.01(0.01)$ \\
\hline Females & $-4.04(1.42)^{* * *}$ & $-3.83(1.52)^{* *}$ & $-3.77(1.52)^{* *}$ & $-3.18(1.52)^{* *}$ \\
\hline 7-16 year-old & $-0.87(2.77)$ & $-1.61(1.62)$ & $-1.61(1.62)$ & $-1.47(1.60)$ \\
\hline 17-25 year-old & $1.60(1.73)$ & $1.47(1.27)$ & $1.45(1.27)$ & $1.44(1.26)$ \\
\hline 26-35 year-old & $0.85(2.37)$ & $1.18(1.51)$ & $1.17(1.50)$ & $1.47(1.49)$ \\
\hline 36-66 year-old & $4.83(1.70)^{* * *}$ & $3.92(1.27)^{* * *}$ & $3.97(1.27)^{* * *}$ & $4.11(1.26)^{* * *}$ \\
\hline $67+$ year-old & $8.10(1.80)^{* * *}$ & $10.10(1.54)^{* * *}$ & $10.13(1.53)^{* * *}$ & $9.93(1.53)^{* * *}$ \\
\hline Widowed & $1.03(2.28)$ & $-6.07(2.12)^{* * *}$ & $-6.03(2.13)^{* * *}$ & $-5.80(2.12)^{* * *}$ \\
\hline Divorced & $-0.60(1.40)$ & $2.22(1.44)$ & $2.19(1.44)$ & $2.22(1.43)$ \\
\hline Unmarried & $-0.29(0.75)$ & $-0.89(0.77)$ & $-0.84(0.78)$ & $-0.82(0.77)$ \\
\hline Spatial spillover & & & $0.03(0.27)$ & $0.08(0.01)^{* * *}$ \\
\hline
\end{tabular}




\begin{tabular}{|l|l|l|l|l|}
\hline $\mathrm{R}^{2}$ & 0.95 & 0.93 & 0.93 & \\
\hline LogL & -637.9 & -467.3 & -467.3 & -465.4 \\
\hline AIC & 1361.8 & 1030.6 & 1030.6 & 1026.8 \\
\hline LR test vs. OLS & & $341.2 * * *$ & $341.2 * * *$ & $345.0^{* * *}$ \\
\hline LR test vs. SUR & & & 0.0 & $3.8^{* *}$ \\
\hline
\end{tabular}

Note. Numbers in parentheses are standard errors; significance indicated by *** $(1 \%), * *(5 \%), *(10 \%)$

The estimated specifications for medication of cardiovascular diseases are reported in Table 3. Again, the three adjusted specifications appear much similar as opposed to the unadjusted OLS specification, and the R2 for the OLS specification is slightly higher than for the adjusted counterparts. One remarkable difference is that the adjusted specifications points to a substitution between investment in health services and medication for cardiovascular diseases, which is ignored by the OLS specification; this specification in turn stands out by indicating a positive correlation between medication and co-financing. When it come to supply factors, all specifications point to a substitution effect between GP density and medication, a positive correlation between GP expenditure and medication, and a lack of effects of GP and specialist visits on medication. Furthermore, the specifications agree on the regional distribution of medication, as the figure is higher for all regions than for the capitol region, and they all points to higher numbers of medicated in urban areas. Regarding sociodemographic conditions, all models points to negative effects of educational level and percentage of females on medication for cardiovascular diseases, while the adjusted specifications indicates a positive relationship between number of children out of home and medication, which is ignored by the unadjusted model. The latter, however, stands alone by indicating significant effects of social benefit receivers and out-commuting, which are not confirmed by the adjusted counterparts. Next, not surprising, effects of age structure are found, as municipalities with many medium aged and elder inhabitants have higher levels of medication for cardiovascular conditions. Finally, the tendencies to spatial clustering of medication levels, which were observed in Figure 2 above, seems to be very weak when adjusting for the effects of the explanatory variables.

Table 4. Estimated specifications for asthma / COL

\begin{tabular}{|l|l|l|l|l|}
\hline & OLS & SUR & SAC-SUR & SAR-SUR \\
\hline Constant term & $-214.1(150.6)$ & $130.8(116.2)$ & $137.6(115.4)$ & $89.65(110.4)$ \\
\hline Health policy & $-0.71(0.99)$ & $0.16(0.38)$ & $0.31(0.37)$ & $0.28(0.38)$ \\
\hline Co-financing & $4.41(3.24)$ & $2.27(1.54)$ & $2.02(1.57)$ & $2.12(1.50)$ \\
\hline Prevention & $-5.38(9.77)$ & $3.95(4.27)$ & $3.24(4.23)$ & $3.67(4.13)$ \\
\hline Health services & $-10.96(15.98)$ & $-6.54(10.45)$ & $-9.39(10.11)$ & $-9.74(10.10)$ \\
\hline Health care & $-2.55(9.68)$ & $2.82(4.26)$ & $2.21(4.18)$ & $1.90(4.12)$ \\
\hline GP density & $-2.01(5.68)$ & $-6.42(4.69)$ & $-7.08(4.40)$ & $-6.24(4.46)$ \\
\hline GP practice density & $-2.06(4.98)$ & $2.07(4.91)$ & $3.97(4.54)$ & $2.35(4.60)$ \\
\hline GP visits & $1.31(1.28)$ & $1.74(1.26)$ & $1.70(1.20)$ & $1.86(1.19)$ \\
\hline GP expenditure & $-4.17(7.22)$ & $-6.26(5.62)$ & $-5.22(5.70)$ & $-4.33(5.35)$ \\
\hline Specialist visits & $-0.27(4.59)$ & $6.74(3.92)^{*}$ & $4.64(4.01)$ & $4.88(3.73)$ \\
\hline Zealand & $-2.43(1.65)$ & $-3.26(2.30)$ & $-2.16(2.56)$ & $-2.68(2.09)$ \\
\hline Northern Jutland & $9.90(2.23)^{* * *}$ & $10.24(2.83)^{* * *}$ & $8.42(3.16)^{* * *}$ & $6.64(2.64)^{* *}$ \\
\hline Central Jutland & $6.42(2.27)^{* * *}$ & $5.21(2.97)^{*}$ & $2.83(3.32)$ & $3.39(2.72)$ \\
\hline Southern Denmark & $9.46(2.78)^{* * *}$ & $7.08(3.53)^{* *}$ & $2.59(3.93)$ & $4.08(3.24)$ \\
\hline
\end{tabular}




\begin{tabular}{|c|c|c|c|c|}
\hline Right wing mayor & $0.58(0.92)$ & $-0.45(1.33)$ & $-0.29(1.23)$ & $-0.14(1.20)$ \\
\hline Local / Center mayor & $-0.08(1.88)$ & $0.39(2.72)$ & $-0.58(2.46)$ & $0.38(2.46)$ \\
\hline 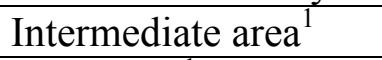 & $-3.73(1.52)^{* *}$ & $-3.07(2.17)$ & $-2.55(1.98)$ & $-2.31(1.98)$ \\
\hline Rural area $^{1}$ & $-5.21(1.99) * * *$ & $-3.37(2.71)$ & $-2.90(2.66)$ & $-2.44(2.48)$ \\
\hline 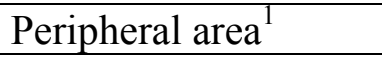 & $-10.28(3.05)^{* * *}$ & $-9.38(3.90)^{* *}$ & $-6.90(3.83)^{*}$ & $-7.08(3.58)^{* *}$ \\
\hline Urbanisation & $-0.14(0.08)^{*}$ & $-0.13(0.11)$ & $-0.07(0.10)$ & $-0.10(0.10)$ \\
\hline Socio-economic & $-1.95(5.71)$ & $1.58(5.16)$ & $2.92(5.04)$ & $1.84(4.89)$ \\
\hline Welfare & $0.01(0.01)$ & $0.01(0.01)$ & $0.01(0.01)$ & $0.01(0.01)$ \\
\hline Unemployment & $1.25(0.49)^{* *}$ & $1.36(0.19)^{* * *}$ & $1.36(0.22)^{* * *}$ & $0.97(0.19)^{* * *}$ \\
\hline Social benefit & $0.60(0.69)$ & $-0.01(0.43)$ & $-0.22(0.41)$ & $-0.07(0.41)$ \\
\hline Sickness benefit & $0.44(1.15)$ & $0.51(0.57)$ & $0.59(0.56)$ & $0.62(0.55)$ \\
\hline Sickness retirement & $1.48(0.59)^{* *}$ & $1.55(0.65)^{* *}$ & $0.93(0.66)$ & $0.96(0.60)$ \\
\hline Children out of home & $-0.15(0.14)$ & $-0.09(0.11)$ & $-0.18(0.11)^{*}$ & $-0.13(0.11)$ \\
\hline Further education & $-0.02(0.19)$ & $0.10(0.22)$ & $0.01(0.22)$ & $0.09(0.20)$ \\
\hline No prof. educ. & $-0.03(0.41)$ & $0.42(0.44)$ & $0.43(0.44)$ & $0.47(0.41)$ \\
\hline In-commuting & $0.06(0.05)$ & $0.02(0.05)$ & $0.01(0.05)$ & $0.03(0.05)$ \\
\hline Out-commuting & $0.01(0.02)$ & $0.01(0.01)$ & $0.01(0.01)$ & $0.01(0.01)$ \\
\hline Females & $-0.75(1.22)$ & $0.41(1.24)$ & $0.10(1.14)$ & $0.40(1.16)$ \\
\hline 7-16 year-old & $6.27(2.38)^{* * *}$ & $-1.23(1.37)$ & $-1.33(1.34)$ & $-1.29(1.33)$ \\
\hline 17-25 year-old & $3.20(1.49)^{* *}$ & $-0.35(1.08)$ & $-0.55(1.04)$ & $-0.66(1.03)$ \\
\hline 26-35 year-old & $4.96(2.03)^{* *}$ & $-0.16(1.26)$ & $-0.69(1.21)$ & $-0.71(1.22)$ \\
\hline 36-66 year-old & $3.32(1.46)^{* *}$ & $-0.17(1.07)$ & $-0.39(1.04)$ & $-0.32(1.02)$ \\
\hline $67+$ year-old & $2.52(1.54)$ & $-0.19(1.24)$ & $-1.87(1.18)$ & $-1.77(1.18)$ \\
\hline Widowed & $0.49(1.96)$ & $0.61(1.72)$ & $1.52(1.70)$ & $0.81(1.62)$ \\
\hline Divorced & $2.84(1.20)^{* *}$ & $0.37(1.19)$ & $0.28(1.19)$ & $0.43(1.11)$ \\
\hline Unmarried & $-1.12(0.64)^{*}$ & $-1.09(0.63)^{*}$ & $-0.51(0.66)$ & $-0.50(0.59)$ \\
\hline Spatial spillover & & & $0.37(0.14)^{* * *}$ & $0.35(0.05)^{* * *}$ \\
\hline $\mathrm{R}^{2}$ & 0.54 & 0.47 & 0.43 & \\
\hline LogL & -587.0 & -412.2 & -406.3 & -401.4 \\
\hline AIC & 1260.1 & 920.5 & 908.7 & 898.7 \\
\hline LR test vs. OLS & & $349.6 * * *$ & $361.4^{* * *}$ & $371.2 * * *$ \\
\hline LR test vs. SUR & & & $11.8 * * *$ & $21.6 * * *$ \\
\hline
\end{tabular}

Note. Numbers in parentheses are standard errors; significance indicated by *** (1\%), ** (5\%), * $(10 \%)$

Table 4 reports the estimated specifications for medication of asthma / COL. Again, there seems to be a close concert between the three unadjusted specifications as opposed to the unadjusted OLS specification, and the R2 for the OLS specification is somewhat higher than for the adjusted counterparts, as the former reports more significant relationships than the latter. However, the explanatory powers of all specifications are relatively weak. Thus, no effect could be found of either policy variables or supply side factors on medication level for asthma / COL. Regarding geography, there seem to be a higher medication level in northern Jutland and peripheral areas. Turning to sociodemography, the only convincing relationship seems to be a positive one between unemployment and medication. Finally, given the relatively weak connection to the explanatory variables, it is not surprising to see that the substantial tendencies to spatial clustering of medication levels, which where seen in Figure 3, still remain as indicated by the high values of the spillover parameters. 


\section{Conclusion}

The study confirms that careful specification is important in order to obtain correct results. Thus, simple OLS specifications generally tend to overestimate the relationships between medication levels for lifestyle related diseases and a number of explanatory characteristics. With few potential exceptions, the major conclusion is that there are hardly any relationship between municipal health care preventive practice and medication. Though this is in accordance with results from previous investigations, based on data prior to the municipality reform, the conclusion is remarkably strengthened by the present results, which are based on post-reform data. For the health policy debate, this is an important conclusion, as it indicates needs, partly for better municipal instruments for prevention of medication for lifestyle diseases, and partly for better indicators for such municipal efforts.

Furthermore, the study shows that the number of persons medicated for lifestyle diseases must be adjusted for differences in the supply of health care services and differences in socio-economic conditions before it can be applied as an indicator for the morbidity picture in the Danish municipalities.

Finally, certain spatial patterns are found. There seem to be tendencies to local clustering with respect to medication practice, and there seem to be geographical variation, as more inhabitants are medicated outside the capitol area, in particular in the Northern and Southern peripheral areas.

* Correspondence to: Jørgen Lauridsen, Centre of Health Economic Research (COHERE), University of Southern Denmark, Campusvej 55, DK-5230 Odense M, Denmark, E-mail: jtl@sam.sdu.dk 


\section{References}

Anselin L 1988: Spatial econometrics: Methods and models. North-Holland: Kluwer Academic Publishers.

Bech M, Lauridsen J 2008: Exploring the spatial pattern in hospital admissions. Health Policy 87: 50-62.

Bech M, Lauridsen J 2009a: Variationsmønstre i hospitalsindlæggelser - har kommunerne kontrol over hospitalsindlæggelserne? I: Jørgen Lauridsen og Kjeld Møller Pedersen (red.):

Sundhedsøkonomi - fra teori til praksis, Jurist- og Økonomforbundets Forlag, side 75-90, København.

Bech M, Lauridsen J 2009b: Exploring spatial patterns in general practice expenditure. European Journal of Health Economics 10: 243-54.

Bech M, Lauridsen J 2009c: Exploring the small area variation and spatial patterns in outpatient treatments. Health Services and Outcomes Research Methodology 9: 177-96.

Bech M, Lauridsen J, Lopez F, Sanchez M 2010: Dynamic patterns and small-area variation in public pharmaceutical expenditure. I: Christian Dreger, Reinhold Kosfeld and Matthias Türck (red.) Empirische Regionalforschung Heute - Festschrift für Professor Dr. Hans-Friedrich Eckey, side 159-78. Wiesbaden: Gabler.

Case A, Rosen H, Hines J 1993: Budget Spillovers and Fiscal-Policy Interdependence - Evidence from the States. Journal of Public Economics 52: 285-307.

Costa-Font J, Pons-Novell J 2007: Public health expenditure and spatial interactions in a decentralized national health system. Health Economics 16: 291-306.

Di Matteo L, Di Matteo R 1998: Evidence on the determinants of Canadian provincial government health expenditure 1965-1991. Journal of Health Economics 17: 211-28.

Gerdham U, Johnsson B 2000: International comparisons of health expenditure: theory, data and econometric analysis. I: A.J. Culyer og J.P. Newhouse (red.) Handbook of Health Economics, Amsterdam: Elsevier.

Giannoni M, Hitiris T 2002: The regional impact of health care expenditure: the case of Italy. Applied Economics 34: 1829-36.

Joines J, Hertz-Picciotto I, Carey T, Gesler W, Suchindran C 2003: A spatial analysis of countylevel variation in hospitalization rates for low back problems in North Carolina. Social Science \& Medicine 56: 2541-53.

Lauridsen J, Bech M, Lopez F, Sanchez M 2007: Spatial dynamics of public pharmaceutical expenditure. Case Studies in Business, Industry and Government Statistics (CSBIGS) 1:80-90.

Lauridsen J, Bech M, Lopez F, Sanchez M 2008: Geographic and dynamic heterogeneity of public prescription pharmaceutical expenditure in Spain. The Review of Regional Studies 38: 89-103.

Lauridsen J, Sanchez M, Bech M 2010a: Public pharmaceutical expenditure: identification of spatial effects. Journal of Geographical Systems 12: 175-88.

Lauridsen J, Bech M, Lopez F, Sanchez M 2010b: A spatiotemporal analysis of public pharmaceutical expenditure. Annals of Regional Science 44:299-314.

Lægemiddelstyrelsen 2010: Befolkningens brug af medicin mod folkesygdomme fordelt på kommuner. http://www.laegemiddelstyrelsen.dk/1024/visLSArtikel.asp?artikelID=12997 (set 26. november 2010). 
Moscone F, Knapp M 2005: Exploring the Spatial Pattern of Mental Health Expenditure. The Journal of Mental Health Policy and Economics 8: 205-17.

Moscone F, Knapp M, Tosetti E 2007: Mental health expenditure in England: A spatial panel approach. Journal of Health Economics 26: 842-64.

Newhouse J 1977: Medical care expenditure: a cross-national survey. Journal of Human Resources 12: 115-25.

Revelli F 2001: Spatial patterns in local taxation: tax mimicking or error mimicking? Applied Economics 33: 1101-7.

Revelli F 2002: Testing the tax mimicking versus expenditure spill-over hypotheses using English data. Applied Economics 34: 1723-31.

Westert G, Groenewegen P, Boshuizen H, Spreeuwenberg P, Steultjens M 2004: Medical practice variations in hospital care; time trends of a spatial phenomenon. Health \& Place 10: 215-20.

Zellner A 1962: An Efficient Method of Estimating Seemingly Unrelated Regressions and Tests for Aggregation Bias. Econometrica 30: 368-9. 